\title{
Understanding Concepts Through Inquiry Learning Strategy
}

\author{
Sholikhan \\ Departement of Physics Education, Kanjuruhan University, Indonesia
}

\begin{abstract}
This research aims to 1) find out the effect of guided inquiry learning strategies to the Understanding of the concepts, 2) find out the effect of self-regulated learning to the Understanding of the concepts and 3) find out the interaction effect of guided inquiry learning strategies and self-regulated learning to Understanding of the concepts. This research was a quasi-experimental research which used two of class namely the experimental class and control class. The research population was the whole class X Science at Senior High School State (SHSS) 6 Malang City Indonesia, in the odd semester of 2016/2017 academic year. The samples consisted of the experimental class and control class was selected by cluster random sampling. The data analysis used 2way ANOVA. The analysis showed there was the effect of Guided Inquiry learning strategies to Understanding of the concepts, 2) there was the effect of Self-regulated learning to Understanding of the concepts, and 3) there was an interaction effect between guided inquiry learning strategies and self-regulated learning to Understanding of the concepts.
\end{abstract}

\section{Introduction}

Learning paradigm change from teacher-centered learning became student-centered learning is one important way to optimise the learning process that encourages learning to active learning. This change is reflected in the process of learning activities that are the high responsibility of students to their own learning. Dimyanti \& Mujiono (2006), explain that in a learning activity can be said to occur learning activities if the behaviour changes to process in self-learners as a result of an experience. Uno (2008) explains that students should actively participate learning (subject) form of knowledge.

Learning activities can running well, appropriately and successfully, if the learners have to learn strategies that can help them optimise learning activities. Arends (1997) states that learning strategies refers to behaviour and thought processes used learner to the subject. Applied learning strategies can provide added value to the learners are: (a) learning strategy provides the opportunity for learners to apply the way of thinking and a way of learning that best matches for them, (b) learning strategies to cultivate the habit of doing an evaluation on how of thinking, way of learning or other matters relating to their learning activities. According to Slavin (2000), learning strategies should be appropriate to the learning objectives and characteristics of learners. Degeng (1998) suggested that, on the dimensions of constructivist, learning strategies more directed to serve question from the students and the views of students. So that the learning activities more focus on activities such as analysis, comparing, generalising, predicting and hypothesises.

As an effort to improve the quality of learning Reigeluth (1983) explains that designing learning strategies considering the dimension and one alternative strategy are important namely the dimensions of the Management Strategy. In this case, the role of management strategies emphasised as an effort to provide learning instructions. Selection of learning strategies more free, fun, and meaningful for the development of learning outcomes. Learning effective that can build understanding and as the habit of thinking skills, the learner is learning that emphasises the importance of learning as a personal process, each learner to build knowledge and personal experience (Setyosari, 2003). Knowledge and personal experiences built by learners through interaction with the environment and utilise the knowledge-knowledge that has been previously owned. This is in line with the statement of Vygotsky (1978) that the intellectual ability to develop when an individual facing a new experience confusing, and when they tried to overcome the problems posed by the experience, individual linking new knowledge to prior knowledge and construct new meaning. This is in line with the constructivist view that each learner must find and change the information if they want to make it as their own. (Brown et al., 1989; Steffe \& gale, 1995; Stephen et al., 2001).

The reality in schools showed that in managing learning in the classroom, teachers often use learning strategies that can not activate the students. Lecture and discussion became a favourite method used by teachers, its happens because this method is simpler and less troublesome teachers. Sadia (2007) revealed that the dominant teaching methods used by teachers in middle and high school at this point are a lecture $(70 \%)$, discussion method (10\%), demonstration method (10\%), and the experimental method (10\%). In addition Santyasa (2012) revealed that the following model information directly from the teacher to the students $(42.59 \%)$, the classic lecture method (16.67\%), and lectures question and answer $(74.07 \%)$. 
Physics, which is one field of study is considered as a difficult subject, boring and terrifying for the students (Druxes, 1986), and often taught by teachers by way of lectures, question and answer or discussion. Teachers more active role as controller and transferring knowledge, limiting the space for students to develop their potential for the creation of a deep understanding of the concept. This is not in line physics content consisting of products, processes and attitudes. Educated the physics is not enough just to educate physical product in the form of formulas, concepts or principles of physics, but also must be included learning process and attitudes, namely how the process of obtaining formulas, concepts and principles and apply them in daily life.

Similarly, what happened in SHSS 6 Malang City, based on the observation that in the learning of physics, teachers were more dominant use expository strategy. Expository also called direct learning (Killen, 2009). The teacher explains the material through lectures and question and answer with the students and are given exercises. Students come in the classroom and then listen and record the explanation given by the teacher, and then given exercises. Students are given the opportunity to ask when they are less understood physics materials. At the end of the lesson the teacher gives homework in an attempt to deepen students' understanding. This activity is routinely done by the physics teacher is not without reason, but because of the demands of a written test which only multiple choice makes physics teachers choose the method as part of a strategy of learning physics in SHSS 6 Malang City. The impact of this learning is that students will become passive because just listening to the teacher, students are less involved both physically and mentally in formulating products of physics, because students receive a ready-made formula, students do not feel they have the material being taught the material was taught teachers because teachers sometimes do not fit the needs of students. Finally, impact the value of physics students who are not up to expectations. The value of especially field of study physics class $\mathrm{X}$ includes a lower category, at an average only 70, below the value of another field of study, and the students who meet the minimum completeness less than $70 \%$.

Lack of understanding of the demands of the evaluation of the concept also one of the causes of low student understanding of concepts. It can be seen from questions test or general test more emphasis on the calculate questions which are less reflect mastery of concepts. As expressed Suastra (2006) that the questions test that given the students in the formative tests, summative or more daily tests require students to memorise and repeat information contained in the student textbooks.

Low-level physics learning achievement shows a low understanding of physics concepts to students. Based on interviews with teachers of physics at SHSS 6 Malang City, that the understanding of the concepts of physics for students is still low, it looks at the learning activities of students often find it difficult to change the unit, explains the concept with its own language, distinguish the concept from one another. When students do exercises together they were able to finish. But when the numbers in question are changed, then most students confusion to resolve the question.

In line with this thinking, one being the crucial issue was how to build understanding (Brooks \& Brooks, 1993, Gardner, 1991) and empowering thinking skills (Eggen et al., 1979). in learning, understanding far more important than the achievement (achievement) (Brooks \& Brooks, 1993). One important purpose of learning is to help learners understand the main concepts in a subject, rather than considering the facts that separate (Santrock, 2004).

In order to understand the subject materials of physics well, students are required to carry out practical activities in an attempt to process the temporary acquisition (preliminary ideas) and conduct logical inference (draw up conclusions from the information) to find concepts, physical principle although only in the view of students. That is the concept of physics that students receive not just a mere memory but the concept is accompanied by a logical reason. Students' understanding of the physics material is very important for students. Students' understanding of the concepts of physics in depth requires a change in the mindset of students from the application of expository towards innovative learning. Therefore, in the learning of physics teachers should be able to choose a learning strategy that is able to activate the students physically and mentally, which is able to enhance students' understanding. Learning strategies that can be used in learning physics that is is the strategy of inquiry learning. Learning Strategies of inquiry is one of the constructivist learning strategies, which is suitable for learning physics. The results showed that the inquiry learning can improve student learning outcomes (Widiadnyana (2014), Jaya (2014). Inquiry learning can improve understanding of physics concepts to students (Marnita, 2004; Carol, Kulhthan and Todd, 2006). There are differences between the understanding of physics concept of free and guided inquiry learning (Marheni, et al, 2014; Sadeh and Zion, 2012).

Inside a person's learning the necessary skills to drive themselves deliberately to study measures for the achievement of optimal learning results. Similarly, in the implementation of inquiry learning strategies students' skills needed to guide itself towards action learning. The ability to direct oneself known as Self-regulated learning (SRL). SRL is a process of self-regulation by a man who was studying with his mental prowess transforms into an academic prowess (Zimmerman, 2002). SRL is a self-monitoring process of designing and careful review of the cognitive and affective processes in completing an academic assignment (Hargis, 2000). 
Self-regulation refers to the process that is used by students to focus their thoughts, feelings, and actions systematically to goal achievement (Zimmerman, 2000). The setting of learning itself, pointing to the efforts of a proactive student in learning, as well as how they monitor their behaviour in their efforts to achieve the goals, as well as their self-reflection on development effectiveness. The results showed that the self-regulated learning can improve student learning outcomes were included: (Smith, 2001), (Schunk \& Zimmerman (1994), Eva (2010), Fitriana, (2011), Widiyaningsih (2014).

\section{Research Method}

This research was a quasi-experimental research because not all variables can be controlled. The classes used were classes that already exist, the existing class allows for manipulation but an existing class is not considered equivalent. For that require analysis of the initial ability of students, so really class has the same preliminary capability. Preliminary capability indicated by the value of understanding the concept before treatment is given. This means that the difference in students' understanding of concepts, was caused by the difference in treatment given, that teaching by guided inquiry learning strategies and conventional.The design of the research was $2 \times 2$ factorial design. This research was conducted in SHSS 6 Malang City class X Science. Samples were class X A as an experimental class by guided inquiry learning while class X B by the conventional learning.

Self-regulated learning data obtained through a questionnaire given before the learning, while the understanding of the concept of data obtained through tests given after the understanding of the concept of learning. Understanding of the concepts used in this research adapted from the understanding of the concept according to Anderson. There are 7 indicators of understanding of the concept, namely: interprets, exemplifying, classifying, generalising, inference, categorise and describe (Anderson, et. Al., 2001) Physics materials that became the object of learning was straight motion, parabolic motion and circular motion.

Having obtained the data on self-regulated learning and Understanding of the concepts, then the next step to test data normality and homogeneity of variance. To test the hypothesis used analysis of variance of two paths with a significance level of $5 \%$.

\section{Result And Discussion}

Implementation of the learning was done during the 8 meeting, 7 times learning meeting in the classroom and 1 time for tests.

There are three hypotheses proposed. Hypothesis testing using 2-way ANOVA.

The results of the analysis presented in Table 1. Summary of 2-way ANOVA.

Table 1. Summary of 2-way ANOVA

\begin{tabular}{|l|l|l|l|l|l|}
\hline Source & Type III sum Of Squares & df & Mean square & F & sig \\
\hline Intercept & 280611.178 & 1 & 280611.178 & $2.857 \mathrm{E} 3$ & .000 \\
\hline STRATEGI & 1633.074 & 1 & 1633.074 & 16.626 & .000 \\
\hline SRL & 645.985 & 1 & 645.985 & 6.577 & .013 \\
\hline STRATEGI * SRL & 214.884 & 1 & 214.884 & 4.188 & .034 \\
\hline Error & 6384.549 & 65 & 98.224 & & \\
\hline Total & 296375.000 & 69 & & & \\
\hline Corrected Total & 8736.957 & 68 & & & \\
\hline
\end{tabular}

Based on the analysis 2-way ANOVA in Table 1. obtained the following results; 1) the source of Strategy, obtained sig $=0.000$, because of sig $<0.05$. So Ho1 rejected. This means that there is a difference between understanding the concept of guided inquiry learning with conventional learning. 2) the source SRL acquired sig $=0.013$, because sig $<0.05$. So H02 is rejected. This means that there are differences in understanding of the concept between the students who have high SRL with who have low SRL. 3) the source Strategies * SRL obtained sig 0.034. Because sig <0.05 then the H03 is rejected, it's mean that there is an interaction effect between learning strategy SRL to the understanding of the concept.

\section{The Effect Of Guided Inquiry Learning Strategy To Understanding Of The Concept}

Compared with conventional learning strategies, this strategy has several advantages. The strategy of inquiry learning is a strategy that is based on the theory of constructivism learning. Inquiry learning strategy is one model of learning with an emphasis on student activity in the learning process. In the teaching of Ilmu Pengetahuan Alam (IPA), especially physics, learning through strategies like this will bring a big impact for the positive mental development of students. Because through inquiry learning students have a wide opportunity to explore and discover for themselves what they need, especially in the learning of abstract (Winataputra, in kaswan, 2004). In relation with that, Robert B. Sund stated, discovery occurs when individuals involved, especially in the use of mental processes to find some of the concepts. A student must use all his ability and 
wherever possible act as a scientist (scientist) who performed experiments and able to perform the mental process of inquiry described the stages that must be passed. Guided inquiry learning is a learning strategy that seeks to instil the basics of scientific thinking on students, so in this learning process students are learning themselves, develop their creativity in solving problems. So the students actually placed as the subject of the study. Kourilsky (Hamalik, 2004), states that teaching based on student-centered inquiry, where students are exposed to a problem and then seek answers through the procedures outlined clearly and structurally. With an emphasis on the process of finding directly by students, the understanding of the concept of problem-solving skills by students may also increase. The results showed there are significant differences between the two groups of students were given a free inquiry learning and guided inquiry.

Students who learn through free inquiry more satisfied and they feel they receive greater benefits from the implementation of the project than the student learning through guided inquiry (Sadeh and Zion, 2011). On the other hand, regarding the documentation of all learning, students guided inquiry believe that they perform better documentation, compared with their peers who study through free inquiry. For the time required, there is no difference, but a significant difference was found in time to experience difficulties arising on the various stages of the investigation process: students who learn through free inquiry believe that they spend more time on the first stage of the project, while students guided inquiry believe that they spend more time in writing a final project. In addition, other differences are found: students who learn through free inquiry feel more involved in their projects, and feel a greater sense of cooperation with others, compared with students guided inquiry.

\section{The Effect Self-Regulated Learning To Understanding Concepts}

There are many factors that can affect the acquisition of one's learning, both externally and internally. One of the internal interest factors and actual to be studied is self-regulated learning of students. Informal education, there is a clear objective, namely: to repair and renew skills, search for new knowledge, and solve problems in life. This is a capital that should be owned by the students to be able to develop the skills and selfregulation have been proven to provide a specific description of the various components that influence the success (Smith, 2001). Similarly, with the support of the good aspects of the personality of students, including attitudes, interests, as well as a positive self-concept acquisition is expected to support the achievement of learning which is understanding the concept of optimal. Someone who has a high interest in learning, then its attention to learning will be also high, in turn, will enhance the understanding of its concepts. Students 'ability to determine, manage, resolve, self-control, and implement learning activities will also determine students' understanding of the concept.

\section{The Interaction Effect Between Guided Inquiry Learning Strategies And Self-Regulated Learning To The Understanding of the Concepts.}

Self-Regulated Learning is the student learning active individuals to achieve academic goals by controlling behaviour, motivating yourself and using cognitive learning (Pintrich (1995). In summary, Zimmerman (1989) suggested that the Self-Regulated Learning students can be the observed extent of their active participation in directing the metacognitive processes, motivation and behaviour when they learn. The metacognitive process is a process in which the student is able to steer themselves while learning, able to plan, organise, orient themselves and perform self-evaluation at various levels during the process of obtaining information. Self-regulated learning is the capacity of personality that includes motivational self-directed (Pervin, 2010). SRL play a role in directing the student to have independence in learning. A self-regulated learner that either has a combination of academic learning skills and self-control which makes learning so much easier so that they are more motivated. Students who have a high ability in managing to learn, can transform their mental abilities into skills and academic strategies (Woolfolk, 2009). Students who are high SRL capabilities will be more independent in learning. They are better able to regulate their own learning, and not depend on others to perform learning activities.

Students who have high self-regulated learning has a strong desire to achieve goals (Schunk \& Zimmerman (1994), and was able to think and act creatively, full of initiative and not just imitated, and not depend on others. In the study, students who self would rather be given the opportunity to learn which enable them to organise their own activities. They are better able to develop themselves if prepared learning conditions that give freedom to explore their abilities. Inquiry learning strategy in principle is to encourage students to learn more active, collaborative and initiative. Therefore, for students with high learning ability SRL using inquiry learning strategy will be increasingly able to achieve a high understanding of the concept, as they are facilitated to do problem-solving, the process of the inquiry, to be creative in the work, initiative, and collaborate. 


\section{Conclusion}

Based on the analysis of research and discussion, it can be concluded as follows:

1. There is a difference between understanding the concept of guided inquiry learning with conventional learning.

2. There is a different understanding of the concept between students who have high self-regulated learning with low self-regulated learning;

3. There is an effect of interaction between learning strategy and self-regulated learning to the understanding of the concept.

\section{References}

[1]. Amelia, E, Awaluddin Tjalla. Hubungan antara Self Regulated Learning Dengan Kemampuan Memecahkan Masalah Pada Pembelajaran Matematika Pada Si swa SMUN 53 Di Jakarta Timur.

[2]. Anderson, L.W., Krathwohl, D.R., Airasian, P.W., Cruikshank, K.A., Mayer, R.E., \& Pintrinch, P.R. (2001). A Taxonomy for Learning, Teaching, and Assesing: A Revision of Bloom's Taxonomy of Educational Objectives. Newyork: Longman.

[3]. Anni, C.T. (2005). Psikologi Belajar. Semarang : UPT UNNES Press

[4]. Arends, R.I (2004). Learning to Teach. 6 th Edition. New York: Mc Graw-Hill

[5]. Arikunto. (1992). Prosedur Penelitian Suatu Pendekatan Praktek. Jakarta PT. Rineka Cipta

[6]. Arrends, R.I. (1997). Classroom Instructional Management. New York: McGraw-Hill Company.

[7]. Butler, D.L. (2002). Individualizing Instruction in Self-Regulated Learning.

[8]. Daryanto, H. M. (2005). Evaluasi pendidikan. Jakarta: Rineka Cipta

[9]. Degeng, I.N.S. (1989). Ilmu Pengajaran Taksinomi Variabel. Jakarta: Depdikbud, Ditjendikti, P2LPTK.

[10]. Dimyati \& Mujiono. (2006). Belajar dan Pembelajaran. Jakarta: Rineka Cipta.

[11]. Druxes, H. (2006). Kompandium Didaktik Fisika. Bandung: Remaja rosda Karya.

[12]. Eggen, P.D., Kauchak, D.P. (2007). Educational psychology: Windows on Classroom 7th Ed. Upper Saddle River, NJ: Pearson.

[13]. Eva, L. (2010). Strategi Self Regulated Learning dan Prestasi Belajar: Kajian Meta Analisis. Jurnal Psikologi Volume 37, No. 1, Juni 2010: $110-129$

[14]. Gagne, N \& Berliner, D. (1992). Educational Psychology ( $\left.5^{\text {th }}\right)$ Priceton. New Jersey : Houghton Mifflin Company

[15]. Gulo, W. (2008). Strategi Belajar-Mengajar. Jakarta: Penerbit Grasindo.

[16]. Hamalik, O. (2007). Proses Belajar Mengajar. Jakarta: Bumi Aksara.

[17]. Hargis, J. The Self-Regulated Learner Advantage: Learning Science on the Internet.

[18]. http//articles.findarticles.com/p/articles/mi_mOQM/is_2_41/ni_90190495.

[19]. Hudojo, H. (2001). Pembelajaran Menurut Pandangan Konstruktivisme. Makalah Semlok Konstruktivisme. FMFISIKA UM 9 Juli 2001.

[20]. Jaya, I.M. , I. W. Sadia, I.B.P.Arnyana. (2014). Pengembangan Perangkat Pembelajaran Biologi Bermuatan Pendidikan Karakter Dengan Setting Guided Inquiry Untuk Meningkatkan Karakter Dan Hasil Belajar Siswa SMP. e-Journal Program Pascasarjana Universitas Pendidikan Ganesha Program Studi IPA . Vol 4, 2014.

[21]. Joyce, B., Weil, M., \& Calhoun, E. (2009). Models of Teaching. Alih bahasa: Achmad Fawaid dan Ateilla Mirza. Yogjakarta: Pustaka Pelajar

[22]. Kemendikbud. (2013). Materi Pelatihan Guru Implementasi Kurikulum 2013 Jakarta: Kementerian Pendidikan dan Kebudayaan.

[23]. Killen, R. (2009). Using direct instruction as a teaching strategy' In: Effective teaching strategies : lessons from research and practice. 5th ed. South Melbourne, Vic. : Cengage Learning, 2009. Chapter 5, pp. 117-145

[24]. Laila, F. (2014). Pengaruh Model Pembelajaran Cooperative Tipe Group Investigation (GI) Dan STAD Terhadap Prestasi Belajar Matematika Ditinjau Dari Self regulated learning Siswa. Prosidding ISBN : $9778-979-16353-6-3$

[25]. Marheni, N. P. I Wayan Muderawan, I Nyoman Tika. (2014). Studi Komparasi Model Pembelajaran Inkuiri Terbimbing Dan Model Pembelajaran Inkuiri Bebas Terhadap Hasil Belajar Dan Keterampilan Proses Sains Siswa Pada Pembelajaran Sains SMP. eJournal Program Pascasarjana Universitas Pendidikan Ganesha Program Studi IPA (Volume 4 Tahun 2014)

[26]. Muslich, M. (2007) . KTSP dasar pemahaman dan pengembangan . Jakarta: Bumi Aksara.

[27]. Paris, S. G., \& Paris, A.H. (2001). Classroom apllications of research on self-regulated learning. Educational Psychologist. $36(2), 89-101$.

[28]. Pervin, L.A., Cervone, D., \& John, O.P. (2010). Psikologi kepribadian: Teori \& Penelitian. Edisi Kesembilan. Terjemahan. Jakarta: Kencana Prenada Media Group.

[29]. Pintrich, P.R. \& De Groot, Elisabeth V. (1990). Motivational and Self- Regulated Learning Components of Classroom Academic Performance. Journal of Educational Psychology, 82( 1), 33- 40.

[30]. Pintrich. P.R. (1995). Promotion Of Self Regulated Learning. http://dwb.unl.edu/Book/CH09/ Chapter09w.html. Diakses 6 Juni 2007.

[31]. Reigeluth, M.C. (1983). Instructional-Design Theories and Models: An Overview of Their Current Status. Mahwah. New Jersey: Lawrence Erlbaum Assosiates Publisher Hillsdale.

[32]. Sadia, I W., Subagia, W., \& Natajaya, W. (2007). Pengembangan model dan perangkat pembelajaran untuk meningkatkan keterampilan berpikir kritis (critical thinking skills ) siswa Sekolah Menengah Pertama (SMP) dan Sekolah Menengah Atas (SMA). e-Journal Program Pascasarjana Universitas Pendidikan Ganesha Program Studi IPA (Volume 4 Tahun 2014)

[33]. Sanjaya (2006). Strategi Pembelajaran. Bandung: Kencana Prenada Media

[34]. Sanjaya, Wina. (2008). Kurikulum dan Pembelajaran: Teori dan Praktik Pengembangan KTSP. Jakarta: Kencana Prenada Media Group.

[35]. Slavin, R.E. (2000). Educational Psychological: Theory and Practice. Sixth Edition. Boston: Allyn \&Bacon

[36]. Smith, P.A. (2001). Understanding self-Regulated Learning and Its Implications for Accounting Educator and Research. Issues in Accounting Education, 16 (40): 663-667.

[37]. Tang, E.L. (2012). Self-regulated learning between low-, average-, and high-math achievers among pre-university international students in Malaysia. European Journal of Social Sciences. 30 (2), 302-312.

[38]. Tuckman, B.W., (1999). Conducting Educational Research $5^{\text {th }}$ Edition. Orlando Harcourth Brace \& Company

[39]. Uno, H.B. (2008). Model Pembelajaran Menciptakan Proses Belajar Mengajar yang Kreatif dan Efektif. Jakarta: Bumi Aksara. 
[40]. Widiadnyana I W., Sadia I W., Suastra I W. ( 2014). Pengaruh Model Discovery Learning Terhadap Pemahaman Konsep IPA dan Sikap Ilmiah Siswa SMP. e-Journal Program Pascasarjana Universitas Pendidikan Ganesha Program Studi IPA (Volume 4 Tahun 2014)

[41]. Widiyaningsih, N. N.,. I Wayan Karyasa., I Nyoman Suardana,. (2014). Pengaruh Model Self Regulated Learning Terhadap Kemampuan Pemecahan Masalah Dan Kecerdasan Emosional Siswa Sma, Undiksa. e-Journal Program Pascasarjana Universitas Pendidikan Ganesha Program Studi IPA . (Volume 4 Tahun 2014)

[42]. Zimmerman, B. J. (2000). Attaining self-regulation. A social cognitive perspective. In M. Boekaerts, P. R. Pintrich, \& M. Zeidner (Eds.), Handbook of self-regulation.. San Diego, CA: Elsevier Academic Press.

[43]. Zimmerman, B. J. (2002). Becoming a Self-Regulated Learner: An Overview. Theory Into Practice. 41(2), 64-70.

[44]. Zimmerman, B. J \& Schunk, D. H (1989) (Eds). Self Regulation Learning and academis achievement: Theory, researah, and practice. New York : Springer-Verlag. 